\title{
Remittances impacts on schooling in Jordan: analyses with respect to migrant destination
}

\author{
Selim ÇaĞatay ${ }^{*}$ Mehmet Mert ${ }^{\star *}$, Onur Koska ${ }^{\star \star *}$,

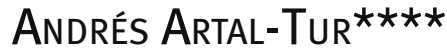

DOI: $10.30682 / \mathrm{nm} 1902 \mathrm{c}$

JEL codes: C21, F22, F24

\begin{abstract}
The two channels that explain how migration of a household member affects human capital formation of those left-behind are income and family disruption effects. In this study, remittances and migration impacts on human capital formation in Jordan is researched with respect to preferred migrant destinations and to the originating governorates of migrants. Jordan's Labour Market Panel Survey-2010 is used to carry out the analyses. Remittances are found to have a positive impact on "schooling", and findings do not change significantly across households with respect to the host country. There is no solid evidence of family disruption, except in households where both parents are absent; however, this is limited with those who have chosen Arab countries as the host. Heterogeneity in the education level of migrants from different governorates does not play a significant role that effects a schooling decision, except for Mafraq.
\end{abstract}

Keywords: Migration, Remittances, Human capital, Income effect, Family disruption Effect.

\section{Introduction}

The World Bank estimated the number of people currently living in a country in which they were not born as being over 200 million; the Bank argues that this number is increasing (Zhunio et al., 2012). High-income economies are expected to be the most popular destinations. Interestingly, however, about half the migrants from developing economies choose other developing economies as the host country. The relationship between migration and development in relatively poor countries is discussed around two main arguments (Leon-Ladesma and Piracha, 2004). The pessimistic view focuses on wealth disparities, and the political and economic unrest created due to the possibility of country of migrant origin becoming more dependent on remittances and the fact that these might only benefit relatively fewer households. On the other hand, the optimistic view approaches remittances as the key instrument in alleviating poverty in the labour-sending countries. Apparently, both views are centred and developed on the impact of remittances, and the debate on the efficient use of remittances as a policy tool still continues (Salas, 2014).

In recent decades remittance flows from migrants have increased substantially. The recorded remittances by migrants originating from developing countries reached US $\$ 338$ billion in 2008 from US\$188 and US\$116 billion in 2005

\footnotetext{
* Akdeniz University, Department of Economics, Turkey.

** Akdeniz University, Department of Econometrics, Turkey.

$* * *$ University of Canterbury, Department of Economics and Finance, New Zealand.

**** University of Valencia, Institute of International Economics, Spain.

Corresponding author: selimcagatay@akdeniz.edu.tr
} 
Table 1 - Top 10 Remittance-Receiving Countries, 2008.

\begin{tabular}{|l|l|c|l|l|c|}
\hline \multicolumn{3}{|c|}{ Ranked by absolute value } & \multicolumn{3}{c|}{ Ranked by absolute value } \\
\hline No. & \multicolumn{1}{|c|}{ Country } & $\begin{array}{c}\text { Remittances } \\
\text { (US \$ Billions) }\end{array}$ & No. & \multicolumn{1}{c|}{ Country } & $\begin{array}{c}\text { Remittances } \\
\text { (\% of GDP) }\end{array}$ \\
\hline 1 & India & 51.9 & 1 & Tajikistan & 45.5 \\
\hline 2 & China & 40.6 & 2 & Tonga & 39.4 \\
\hline 3 & Mexico & 26.3 & 3 & Moldova & 34.1 \\
\hline 4 & Philippines & 18.6 & 4 & Lesotho & 27.7 \\
\hline 5 & France & 15.1 & 5 & Guyana & 25.8 \\
\hline 6 & Spain & 11.8 & 6 & Lebanon & 23.7 \\
\hline 7 & Germany & 11.1 & 7 & Samoa & 22.8 \\
\hline 8 & Poland & 10.7 & 8 & Jordan & 21.7 \\
\hline 9 & Nigeria & 10.0 & 9 & Honduras & 19.1 \\
\hline 10 & Egypt & 9.5 & 10 & Kyrgyz Rep. & \\
\hline
\end{tabular}

Source: World Bank (2008); adopted from (Zhunio et al. 2012).

and 2002 respectively. The growth in total remittances globally is larger than official aid inflows and are second only to foreign direct investment (Mansour et al., 2011). While the remittance share of GDP was about 5\% in low-income countries in 2007, its share was about $1.8 \%$ for middle-income countries in the same year. According to Ratha (2007), remittances represented a more stable source of money during financial crises. While the US continues to be the largest source of remittances, sending a total of US $\$ 47.2$ billion in 2008 , India was the top recipient of remittance inflows in 2008, receiving US $\$ 51.9$ billion; Tajikistan received the highest remittances as a percentage of GDP (45.5\%). Table 1 provides the statistical information on the top 10 recipients of remittances in absolute terms and as a percentage of GDP.

Today, foreign workers, especially unskilled and semi-skilled, represent a significant component of the labour market in Jordan; they fill shortages in the agricultural, construction and service industries. An increasing number of the foreign labour force in Jordan creates an interesting debate when this fact is combined with existing high levels of unemployment among nationals. On the other side of the coin, since the 1973 oil price increases, large outflows of Jordanian workers, mainly highly-skilled, towards the oil-producing countries and overseas have also been observed; these countries continue to be the most important destinations for Jordanians. According to Ratha and $\mathrm{Xu}$ (2008), Jordan, an on-oil middle-income economy, is a labour exporter with a migrant population ratio reaching $11.2 \%$ in 2005 ; this is higher than the $3.3 \%$ emigrants' population average share for middle-income countries.

A quantitative picture of Jordanians abroad is not easy to draw due to scarce and fragmentary statistical information. However, the destination distribution of emigrants could be presented as in Table 2 for the year 2008 (CARIM, 2010). In 2008, about 161,854 Jordanians resided in oil-producing countries, and the majority (more than 95\%) lived in the United Arab Emirates (33.9\%), Qatar (31.5\%), Kuwait (19.0\%), and Oman (11.7\%). In the same year, about 126,311 Jordanians ( $43 \%$ of the total) emigrated to the rest of the world: more than half of these $(56.5 \%)$ were in the US, $19.1 \%$ were in the EU-27, and $13.9 \%$ were in other Southern and Eastern Mediterranean countries. The total number of Jordanian emigrants $(288,165)$ was about $4.9 \%$ of the whole of Jordan's population at the time.

The data limitations constrain the information on emigrant profile to only those residing in OECD countries. However, a fact about Jordanian emigrants is that unlike the majority of Southern and Eastern Mediterranean countries, their profile is very similar in all OECD coun- 
Table 2 - Distribution of Jordanian Emigrants (number).

\begin{tabular}{|l|r|}
\hline Oil-producing countries & 161,854 \\
\hline UAE & 54,834 \\
\hline Qatar & 50,928 \\
\hline Kuwait & 30,748 \\
\hline Oman & 18,888 \\
\hline Saudi Arabia & 3,396 \\
\hline Libya & 3,060 \\
\hline Other countries & 126,311 \\
\hline EU (27) & 24,158 \\
\hline Germany & 7,716 \\
\hline UK & 3,105 \\
\hline Italy & 2,692 \\
\hline Other Southern and Eastern & 17,562 \\
\hline Mediterranean countries & 12,897 \\
\hline Syria & 84,591 \\
\hline Others & 71,306 \\
\hline USA & 7,440 \\
\hline Canada & 288,165 \\
\hline Grand Total & \\
\hline Source: CARIM (2010) & \\
\hline
\end{tabular}

Source: CARIM (2010).

tries; this seems to be determined more by educational conditions at home rather than by destination countries' selective migratory pol- icies (CARIM, 2010). At the time (around the year 2000), women represented $47.6 \%$ of total emigrants. The educational attainment of those emigrants was observed to be highly-qualified; $41.0 \%$ held a tertiary education and $37.8 \%$ a secondary or post-secondary degree. Regarding the occupational position, $28.3 \%$ were employed as legislators, $13.4 \%$ as senior officials and managers, and $11.3 \%$ were employed as technicians and associate professionals (CARIM, 2010).

By looking at the trends in Figure 1, it can be seen that remittances have had a non-ignorable significance as an income source in Jordan since the 1980s. Since the beginning of the 1990s, remittances have increased from US $\$ 500$ million to more than US\$3,500 million in 2012; its share of GDP has changed between $10-25 \%$ in the same period.

According to Mansour et al. (2011), the importance of remittances in the Jordanian economy is accentuated when comparing these inflows to grants, FDI, and export revenues. When compared with US\$1.01 billion in foreign grants, US\$1.97 billion in FDIs, and US\$7.80 billion in export revenues, migrant remittances reached US\$3.17 billion in 2008. Such magnitude is an indication for the potential role of remittances in human capital formation in Jordan, although the relative importance of remittances has seemed to fall since the beginning of the 2000s.

Figure 1 - Remittance Income in Jordan.




Chami et al. (2003) summarize the economic impact of remittances on receiving countries in three major stylized facts. First, it is argued that remittances are mainly spent on household consumption. Second, the main argument is that only a small part of those private transfers tend to be oriented towards savings or investment in both physical and human capital. Finally, investments made possible via remittances yield very limited social returns of any significance, and therefore have limited impact on the overall growth of the economy. On the other hand, more recent empirical research has challenged the prevailing views, and argue that remittances are being used for investments and do have an impact on broader economic development beyond the recipient household. The cornerstone of this hypothesis is that the analysis should stress the difference between expenditure behaviour of remittance receiving families or individuals and non-remittance receivers (Adams, 2005).

Consequently, there has been increased interest in remittances and their role in promoting economic development, and Jordan presents an interesting case due to two factors. First, Jordanian migrants are observed to be relatively better educated (qualified) than average Middle Eastern migrants, and second, remittances occupy a non-ignorable portion of GDP, ranked in the top 10 countries in 2008 (see Table 1).

From the above perspective, in this study it is aimed to investigate how remittance income is influential on Jordanian human capital formation. The theoretical debate is about whether the income effect of remittances is offset by family disruption effects of migration. In other words, the main tested hypotheses are whether remittances help to create a positive effect on children's schooling in the migrant families, and whether this effect persists in the cases when both parents are migrants. The relevant literature provides limited evidence on either of the effects, particularly in the Middle Eastern and Southern and Eastern Mediterranean countries. The theoretical considerations regarding the re- lationship between human capital formation and remittances are summarized in Section 2. In Section 3, the relevant empirical evidence is provided, and Section 4 presents empirical analyses. Finally, the paper concludes with a discussion in Section 5 .

\section{Theoretical Debates}

In their article 'New Economics of Labour Migration', Stark and Bloom (1985) argue that it is mainly market failures that lead people to migrate $^{1}$. For instance, if there is inadequate social security and/or malfunctioning capital markets and/or inadequate or inaccessible insurance policies, households use migration as a strategy to overcome these constraints and try to diversify risks (Stark, 1984; Stark and Bloom, 1985; Katz and Stark, 1986; Stark, 1993).

Stark (1984) argues that even though the migrating unit is the individual, this decision is made by the households because the act of migration is an implicit contract between members of a household. The idea is simple: to share costs and benefits of migration, household members co-finance migration costs for one of the family members in return for a cut of future income gains. Therefore, remittance income is at the core of the New Economics of Labour Migration, in which migrants share their returns to migration with non-migrant household members.

Remittances might become an important source of income for the recipient household if the loss of income due to migration of a household member is overcompensated by such returns to migration. Hence, the migration can alleviate resource constraints of the recipient household, and can generate investment and boost consumption. In some cases, remittances might be used by households for debt payment or loan repayment; however, this does not change the fact that remittances provide flexibility for the household to increase their expenditure on some basic items such as health and education (Stark, 1993; McKenzie and Sasin, 2007).

1 The theoretical literature on international migration presents different explanations as to why people migrate; see Stark, 1984; Stark and Bloom, 1985; Katz and Stark, 1986; Massey, 1990; Massey et al., 1993; 1994 for more elaborate information regarding migration theory. 
From the same perspective, remittances may lead to a decrease in labour supply, or may reduce the need for additional income generated by household members; this is because remittances raise household members' reservation wage, including that of children who are left behind. Apparently, in the households receiving remittance income, young, non-migrant household members might have a greater opportunity to have time for school; this occurs when remittances are large enough to loosen budget constraints (Elbadawy and Roushdy, 2010). The positive income effect that might be created by remittances is given so far; however, the opposite impact might also become the case in other households.

For example, remittances might be invested in a family-run venture for which young household members can provide their unskilled labour in the future. It might also be the case where remittances are saved to finance a young household member's migration in the future. Obviously then, remittances may have a detrimental impact on the schooling of children. The decision to invest in education depends on whether or not the prospect of migrating creates incentives to invest in education, as Stark et al. (1997) argue. Remittances that loosen liquidity constraints may have a positive impact on human capital formation if there is positive selection into migration, such that the probability of migrating and that of successful migration increase with education. However, as Stark and Byra (2012) argue, remittances may fail to foster human capital formation and may hamper schooling if migration of an unskilled household member leads to expectations that unskilled work will be rewarding without schooling.

In addition to these negative income effects of remittances, family disruption may also occur and may adversely impact human capital formation. Family disruption channels may work out in the absence of a parent, resulting in an adverse impact on school attendance and school performance (Kandel and Kao, 2001). Moreover, when the loss of income due to migration of a household member is not yet offset by remittances (which may take some time to arrive), the adolescent children may be called on to contribute to household income, especially in the short run. In crowded households, young, non-migrant household members may have less time for school if the restructuring of roles due to parental absence increases their domestic workload (care-giving, cleaning, shopping, cooking, etc.).

To summarize, the positive and negative impact of migration/remittances on human capital formation is actually dependent on various factors rather than only the amount of remittances. In other words, whether or not income effect is offset by disruption to the family, is not only based on remittance income but only on the number of household members and siblings, their age and gender distribution, and the educational and occupational advance of the migrant and those household members left behind might become even more important.

\section{Literature Review}

The relevant literature is reviewed, particularly to find evidence with regard to the positive impact of remittances on human capital formation, and to investigate the instrumental variables that are employed to solve possible endogeneity problems in the empirical analyses.

Unfortunately, the number of studies that focus on Middle East and North African (MENA) countries is quite low $^{2}$. Various studies pre-

\footnotetext{
2 Majority of the studies focus on Asian (Yang 2008; Arguillas and Williams 2010; Cortes 2015 (Philippines); Bansak and Chezum 2009 (Nepal); Mansuri 2006 (Pakistan); Piracha and Saraogi 2012; Stöhr 2015 (Moldova); Atamanov and Van der Berg 2012; Kroeger and Anderson 2013 (Kyrgyzstan)) and Latin American countries (Acosta 2011a; b; Edwards and Ureta 2003 (El Salvador); Boucher et al. 2009; Alcaraz et al. 2012; Hanson and Woodruff 2003; Cuecuecha 2009; McKenzie and Rapoport 2011; Antman 2011; Lopez-Cordova 2005; Kandel and Kao 2001 (Mexico); Amuedo-Dorantes et al. 2010; Bredl 2011 (Haiti); Amuedo-Dorantes and Pozo 2010 (Dominican Republic); Calero et al. 2009 (Ecuador); Adams and Cuecuecha 2010 (Guatemala); Robles and Orepesa 2011; Salas 2014 (Peru)). In addition two studies were found that focus on low- and middle-income countries (Zhunio et al., 2012) and on Central and Eastern Europe countries (Leon-Ledesma and Piracha 2004).
} 
ferred to look at how consumption patterns are affected and changed in the remittance recipient households. The evidence is mixed, but the majority could be said to have found that remittances are used mainly to finance non-productive investments and spent on conspicuous consumption (Rapoport and Docquier, 2006; Yang, 2008; Boucher et al., 2009; Schapiro, 2009; Adams and Cuecuecha, 2010; Adams Jr., 2011; and Ratha et al., 2011). Leon-Ledesma and Piracha (2004) is an exception to this case; they found remittances have a positive impact on productive investment.

The econometric studies that specifically focus on the impact of remittances on human capital use average years of schooling, school attendance, school enrolment and the highest grade completed as dependent variables. The general finding is that those dependent variables are positively affected by remittances, however, the results change with respect to gender and age groups. In some studies, non-migrant household members' reservation wage was found to increase due to the effect through the income channel, and therefore the need for additional income generated by young household members decreased (Mansuri, 2006; Yang, 2008; Calero et al., 2009; Acosta, 2011a,b; and Alcaraz et al., 2012).

Various studies found family disruption caused by migration to be significant, and adversely impacted human capital formation (Cuecuecha, 2009; Antman 2011; McKenzie and Rapoport 2011; Robles and Oropesa 2011; Kroeger and Anderson 2013). Cortes's (2015) research is an interesting example of the family disruption effect in that the analysis differentiates the effect with respect to the parent in the migrant household. Cortes found that in households with a migrant mother, children lag behind in school compared to children with migrant fathers (Cortes, 2015).

On the other hand, Salas (2014), unlike the others, found that international remittances have a positive impact on the probability of acquiring a higher quality of education by sending children to private schools. Similarly, Zhunio et al. (2012) found that remittances have a positive impact both on schooling and health conditions. An interesting finding is given in Atamanov and Van der Berg (2012) regarding the effects of migration and remittances on crop income, in that the overall effects of migration on crop income is negative for permanent migrants and for seasonal migrants from the largest farms, while seasonal migration from smaller farms has a positive overall impact on crop income.

There are only a few studies that look at both the family disruption effect of migration and the income effect of remittances. Among these Cuecuecha (2009) and Amuedo-Dorantes et al. (2010) found that the overall effect is positive and significant, but Cuecuecha (2009) found that the overall effect is positive only in the case of migrants who left their households for less than five years.

Contrary to all the above, Piracha and Saraogi (2012) investigate the factors that affect remittance flows. Their findings present that the composition of the household, migrant characteristics, and some community-level variables are the key elements in explaining remittance behaviour.

The four studies that are found on Egypt are Elbadawy and Roushdy (2010), Binzel and Assaad (2008, 2011), and Koska et al. (2013). Elbadawy and Roushdy (2010) address the family disruption effect of migration in Egypt by including a binary variable that indicates whether or not the child lives in a household that has a migrant member who migrated within the last five years; they found no statistically significant impacts on school attendance. Binzel and Assaad $(2008,2011)$ address similar questions in Egypt, but their findings are quite mixed. Koska et al. (2013) in general found some evidence of a positive impact of remittances on child schooling, but family disruption can become true if both parents are absent as migrants. In addition, the age that people start work in Egypt is observed to increase with the effect of remittances; however, this result is statistically stronger for males.

With regard to Jordan, Mansour et al. (2011) is the only study that specifically focuses on the impact of remittances on human capital accumulation among youths. While Mansour et al.'s (2011) objectives show some similarities with this research, there are also some dissimilarities 
with respect to empirical specifics, methodology and findings. One of the similarities appears in the way both papers proxy human capital. Both papers specifically focus on "schooling". Mansour et al. (2011) uses school attendance and education attainment to quantify the schooling impacts, while this research uses various levels of schooling for the same purpose. The database used to carry out the econometric analyses are different: this research employs the Jordan Labour Market Panel Survey-2010, while Mansour et al. (2011) uses Jordan Household Income and Expenditure Survey-2006. However, the control variables used in both papers are quite similar to each other such as household, parental and regional characteristics of the migrants. In general, econometric methodologies of the papers can be considered as quite similar but instrumental variables utilized in both papers are quite different. In addition, in this research the way of quantifying the family disruption effect is quite unique. This research focuses on the migration disabling and remittances enabling effects in Jordan in order to reveal the joint remittances-migration impacts on human capital formation. In other words, the two effects are put against each other in order to uncover the specific effect of each and their joint impact as well. With respect to findings, it could be that the two most significant differences are that Mansour et al. (2011) found that the impact of remittances on schooling do change by gender (which this research does not), and the family disruption effect might offset the positive income effect, which is a finding in this research only.

\section{Empirical Framework}

\section{Database}

The data extracted from Jordan's Labour Market Panel Survey-2010 (JLMPS) ${ }^{3}$ are employed to carry out the analyses. JLMPS aims to provide statistical data about the demographic, social and economic characteristics of the population, and the labour force and economically active population in particular. The survey is implemented on a sample of 5,000 households distributed nationwide. It uses a stratified clustered random sample that is broken down in two phases in order to ensure representative results on the national, urban, rural, region and governorate 4 levels.

The main objectives of the survey involve providing detailed data on the Jordanian labour market conditions, substantial differences that take place due to labour mobility, and as a result of the difference in wages caused by differences in individuals' education, age, marital status, housing, etc. The survey intends also to introduce indicators about domestic and external immigration, and household expenditure trends in Jordan. The detail included under 'migration' is of particular interest to us because it includes information on international migration, gender, age, education, and employment history of household migrant members, as well as their remittances. In particular, the survey provides information on whether or not a household receives remittances from a migrant member: the number of migrants in the household, and amount of remittances received are also included. In addition, those migrants can be grouped with respect to their home district and governorate and to the host countries.

\section{Sample}

In the analyses, the specific focus is migrant households, defined as households that have at least one member currently living abroad. Those households that have at least one member receiving any cash and/or in kind benefit from another member of the same household living abroad are accepted as remittance-receiving households. Various descriptive statistics of migrant households are given in Table A1.

\footnotetext{
3 http://www.erfdataportal.com/index.php/catalog.

${ }^{4}$ Jordan is divided into 12 governorates by the administrative divisions system of the Ministry of Interior. There are four governorates under each main region: north, central and south. The three geographical regions are not distributed by area or population, but rather by geographical connectivity and distance among the population centres. The sample used in the survey covers all governorates in north and central regions and one governorate from south region.
} 
The majority of the migrants seem to prefer major oil exporting Arab countries (Table A2). This might be due to both cultural and lingual similarity, but at the same time those countries might pay well compared to other destinations, especially if the migrants are well educated. In Table A3, it is observed that almost $75 \%$ of total migrants to major oil exporting Arab countries have at least an interim diploma, and about $50 \%$ have a postgraduate degree. Therefore, our expectation regarding income might not be an exaggeration.

The second most preferred destination is the USA; European countries only receive $7 \%$ of total migrants from Jordan. The EU and Jordan have only very recently established a Mobility Partnership, hence the figures in Table 4 and the survey data used in the analyses do not account for the impact of this agreement ${ }^{5}$. By looking at the distribution rates in Tables A1 and A2, we might conclude that the selected sample in the survey quite successfully proxies the population. In addition, information on the educational background of the migrants (Table A3) shows consistency with the information provided in the introduction section, showing that more than $50 \%$ of migrants to all destinations have an interim diploma and over; the exception is the "Other Arab Countries" group, where about $65 \%$ of migrants have a vocational school or lower level diploma.

Table A3 also presents educational divergences among migrants from different Jordan governorates. While more than $90 \%$ of migrants from Ajloun and Karak have either an interim diploma or a higher degree, about $30 \%$ of migrants from Balqa and Mafraq governorates have only basic education. Therefore, the heterogeneity among governorates in educational level of migrants raises the question about whether the schooling impacts of remittances changes with respect to the governorate. The reason behind the high percentage of migrants with only basic education in Balqa and Mafraq might be lack of job opportunities, even for the low qualified labour force. Therefore, in these two regions remittances might be used to source investments rather than education. In other words, it would be interesting to see if there would be statistically significant differences among governorates with respect to the effects of various explanatory factors.

\section{Methodology}

In this sort of analysis, endogeneity and self-selection problems might become common for at least two reasons. The first is that households are not randomly selected into migration or because the simultaneity of household decisions, measurement errors, and omitted variable or reverse causality bias, estimation results might be biased. The second reason is that there may be systematic differences, especially in terms of socio-economic and demographic characteristics of households, between migrant and non-migrant households, and/or between migrant households receiving remittances and those receiving no remittances. For instance, CARIM (2010) puts forward the self-selection problem with a descriptive work such that more educated Jordanian migrants prefer to choose oil rich countries (Saudi Arabia, Kuwait, United Arab Emirates, Qatar, Libya) as their host country, especially after 1973 . In addition, geographical positions of migrants' home districts, such as closeness, sharing a border, etc., might put another bias on estimators.

In an econometric equation using an instrumental variable ${ }^{6}$ among explanatory factors is a common approach of dealing with endogeneity and selection bias problems. The same route is also followed in the analysis in this study. However, in this specific case (the causal relationship between remittances and schooling), finding an instrumental variable is not that easy. The chosen variable should be sufficient-

\footnotetext{
5 The details of the agreement is available at http://europa.eu/rapid/press-release_IP-14-1109_en.htm.

6 The empirical literature suggests the use of various variables as instruments, such as share of households with migrants, distance to border, historical migration rates, share of remittance receiving households, Asian financial crisis, household head's past migration experience, weekly earnings of Hispanic workers in the US, state level unemployment, and average real earnings.
} 
ly correlated with migration and/or remittances and should not affect the schooling decisions directly (by no other means through its correlation with migration and/or remittances). Another problem is self-selection; this is addressed by focusing on a group of households that has at least one migrant member abroad as the sample. Therefore it is already assumed that the family disruption channel may already be present (as is done in this study). What is investigated, therefore, is whether or not the disruption effect is overcompensated by the income channel.

Equation 1 specifies the searched implicit relationship that is used to test the first hypothesis, "whether remittances help to create a positive effect on children's schooling in migrant families". Equation 2 specifies the searched second implicit relationship that is used to test the hypothesis, "whether the positive impact on schooling persists in the cases when both parents are migrants". The effects of various factors on three outcome variables $(y)$ are estimated. The explanatory factors are composed of individual characteristics ( $x$ : gender, age, number of siblings, years repeated or ever repeated in the school), household characteristics ( $w$ : number of household members, location [rural/ urban Jordan or northern/middle/southern Jordan], house ownership), parental characteristics ( $p$ : parents' education level, both parents' present), and migrant characteristics ( $l$ : education level, years since last visit, years gone, home district, host country).

In the first equation, whether or not the household receives remittance is controlled with an intercept dummy $(R)$, and in the second equation the individual effect of remittances when both parents are absent $(R \& A)$ as migrants is also controlled. While $R$ represents the income effect, $R \& A$ reflects the family disruption effect. To represent schooling, three outcome variables are used: the first two are binary variables. They get value 1 if the child's schooling level is secondary school and over, and undergraduate and over respectively. The third is a categorical variable, which takes value from 0 to 7 with respect to the changing level of schooling. Subscripts $i, r, h, j$ and $k$ repre- sent individual, region, households, parents and migrants respectively.

$$
y_{i, r}=a_{0}+a_{1} x_{i}+a_{2} w_{h, r}+a_{3} z_{j}+a_{4} l_{k}+b_{1} R_{h}+b_{2}(A)_{h}+u_{i, r}
$$

$y_{i, r}=a_{0}+a_{1} x_{i}+a_{2} w_{h, r}+a_{3} z_{j}+a_{4} l_{k}+b_{1} R_{h}+b_{2}(R \& A)_{h}+u_{i, r}$

Therefore, separate estimations are run to capture the possible positive human capital formation effect of remittances and possible negative effect of migration (family disruption channel) on human capital. In the first equation, two binary variables are included that represent whether or not the household receives remittances and whether or not both parents are absent as migrants (absenteeism). In the second equation, the first remittance dummy variable is included and the absenteeism dummy is dropped. Instead of absenteeism, the remittances dummy is interacted with absenteeism and that new interacting dummy is included. This is done in order to reveal the effect of remittances on human capital formation in the presence of a possible family disruption effect of migration. It is expected that, particularly in households where both parents are migrants, the income effect would be offset by the family disruption effect.

When historical facts are considered in the case of Jordan, two factors play a crucial role in choosing the host country for the migrants: the historical migration network and the oil supply in Arab countries. The two most commonly used instruments in the relevant empirical literature are historical migration rates and the share of households with migrants. By partly departing from most of the applied literature, another instrument, which was first used in Koska et al. (2013), was also used in this study. This instrument is the average oil supply (barrels per day) in the host countries; this is a good measure of the prospect of Jordanian migration. The average oil supply is a good instrumental variable, not only because it is correlated well with Jordanian remittances, but also because it obviously cannot affect Jordanians' schooling decisions by any means other than through its correlation with remittances. Another instrument that might 
be used to replace remittances is the share of migrants in the household ${ }^{7}$.

Based on how the dependent variables were structured, ordinary least square, probit, ordered probit, instrumental variable, and geographical weighted regression techniques were used to estimate the relationships in the specified equations. In all estimations, the first heteroscedasticity problem was checked and, with the existence of the problem models, were re-estimated with consistent estimators. The data belonged to the year 2010, and cross-sections consisted of individuals between 6 and 30 years of age. In most models, the explanatory power of the models were moderate if not poor, but specified explanatory variables passed the joint significance test. Since several estimations were carried out, it was decided not to give the diagnostics of the equations; however, these could be provided on request. To control the unobserved heterogeneity across different governorates and across different destination countries, appropriate fixed effects were used. To deal with endogeneity and selection bias problems, an instrumental variable approach was used. Finally, to see the changing impacts across different governorates, geographically weighted regression was utilized.

\section{Empirical Findings}

Empirical results are given in Table 3. In this table, the first row and first column present explanatory and dependent variables respectively. With regard to schooling, three dependent variables were included. In the second column, estimation methods were written where $\mathrm{Or} \mathrm{Pr}, \mathrm{Pr}$, $I V, O L S$ and GWR stand for ordered probit, probit, instrumental variable, ordinary least square, and geographically weighted regression respectively.

The general estimation and presentation procedures followed was this: for each dependent variable the specified relationship was estimated by using total sample, without dividing it into Non-Arab/Arab groups or by gender. If a statistically significant outcome was found, then the same equation was estimated by using a geographically weighted regression technique to see the changing impacts by governorates. In the first equation, if host country and gender dummy variables had statistically significant coefficients, the total sample was divided into sub-samples and estimations with these sub-samples continued. In this section, more mechanical interpretation is given but more insight is brought in the next section.

Several estimations were carried out using various techniques to find the significance of factors that might explain the variation in "schooling" variables. Among several explanatory factors the same 6-7 variables were found to be statistically significant in most of the estimations.

In the remittance receiving households, the impact on various schooling level variables were quite consistent. In the households where emigrants preferred Non-Arab/Arab countries, there was a positive/negative relationship between remittance receiving and the possibility of higher education. This fact was also valid for 'left behind male children'. Furthermore, the positive relationship between remittance receiving and the possibility of higher education was also observed in households where emigrants preferred Non-Arab countries and in which both parents were absent.

To have a better idea with respect to the effect of household members and siblings, their age, gender, education and occupation distribution should be known and further investigated. In general, the number of siblings was found to cause a fall in possibility of schooling level, whereas the number of household members was found to cause the opposite impact. In order to be able to give a healthy interpretation for this opposite impact, the number of people working in the household, and probably their occupation, should be known.

\footnotetext{
7 Since the instrumental variable "share of migrants in the household" might/would also have an endogeneity problem, a daily oil supply variable was used as an instrument. To test for the validity of this instrument, the rule of thumb, checking the estimated coefficient of the instrument for significance and observing an F-test result that is larger than 10, was used. If the findings were in accordance with what was expected then it was assumed and accepted that the instrument was a valid and strong one.
} 
Table 3 - Estimation Results - Schooling.

\begin{tabular}{|c|c|c|c|c|c|c|c|c|c|c|c|c|c|c|c|}
\hline \multicolumn{16}{|c|}{ Labor force } \\
\hline & Explanatory & \begin{tabular}{|l}
$\begin{array}{l}\text { \# of } \\
\text { siblings }\end{array}$ \\
\end{tabular} & $\begin{array}{l}\# \text { of } \mathrm{HH} \\
\text { members }\end{array}$ & wealth & last visit & $\begin{array}{l}\text { ever } \\
\text { failed in } \\
\text { school-1, } \\
0\end{array}$ & \begin{tabular}{|l|l} 
region \\
middle \\
1,0
\end{tabular} & \begin{tabular}{|l|} 
house \\
owners-1, \\
0
\end{tabular} & $\begin{array}{l}\text { both } \\
\text { parents } \\
\text { absent-1, } \\
0\end{array}$ & \begin{tabular}{|l|} 
if \\
migrant \\
to NA- \\
1,0 \\
\end{tabular} & \begin{tabular}{|l|} 
education \\
migrant \\
basic \& \\
over- \\
1,0 \\
\end{tabular} & \begin{tabular}{|l} 
education \\
migrant \\
secondary \\
\& over- \\
1,0
\end{tabular} & \begin{tabular}{|l|} 
education \\
migrant \\
bachelor \\
$\&$ over- \\
1,0
\end{tabular} & \begin{tabular}{l|l} 
recieves \\
remittances- \\
1,0
\end{tabular} & \begin{tabular}{|l|} 
both par \\
abs \& \\
rec \\
remit- \\
1,0 \\
\end{tabular} \\
\hline \multicolumn{16}{|l|}{ Dependent } \\
\hline \multicolumn{16}{|l|}{$\begin{array}{l}\text { Age first to } \\
\text { start job }\end{array}$} \\
\hline Sample & Methodology & & & & & & & & & & & & & & \\
\hline Total & $\begin{array}{l}\text { OLS } \\
\text { IV } \\
\end{array}$ & $\begin{array}{c}0.25^{* *} \\
0.21^{* *} \\
0.37^{*}\end{array}$ & $-0.28^{* * * *}$ & $\begin{array}{r}0.97 * \\
1.06 * \\
0.12\end{array}$ & & & $\begin{array}{c}-1.55^{*} \\
-1.75 * \\
-1.78 *\end{array}$ & $\begin{array}{l}2.01^{* *} \\
1.88^{* *} \\
2.66^{* *}\end{array}$ & $\begin{array}{c}-1.62 * \\
-2.90 *\end{array}$ & $\begin{array}{r}0.83 \\
0.65 \\
1.11^{* * *} \\
\end{array}$ & & $\begin{array}{l}1.63^{* *} \\
1.89^{* *} \\
1.69^{* 8}\end{array}$ & & $\begin{array}{r}-0.02 * * \\
-1.62^{* *} \\
5.29 *\end{array}$ & $\begin{array}{r}2.43^{* *} \\
-0.5 \\
\end{array}$ \\
\hline Non-Arab & $\begin{array}{l}\text { OLS } \\
\text { IV }\end{array}$ & & $\begin{array}{r}0.06 \\
0.06 \\
0.83^{* * *} \\
0.77 \\
\end{array}$ & & & $\begin{array}{l}3.59 * * \\
3.58 * *\end{array}$ & & & $\begin{array}{r}0.43 \\
-3.13^{* *}\end{array}$ & & $\begin{array}{r}-0.62^{* *} \\
-0.60^{* *} \\
6.45^{*} \\
5.83^{* *} \\
\end{array}$ & & $\begin{array}{c}0.58^{* *} \\
0.57^{* *} \\
-4.31^{* *} \\
-4.17^{* *}\end{array}$ & $\begin{array}{r}0.77^{* *} \\
0.45^{* * *} \\
7.44^{* * *} \\
7.05^{* * *}\end{array}$ & $\begin{array}{r}0.5 \\
-3.30^{* *}\end{array}$ \\
\hline Arab & $\begin{array}{l}\text { OLS } \\
\text { IV }\end{array}$ & $\begin{array}{l}0.97 * \\
0.97 * \\
1.18 * \\
1.15 *\end{array}$ & & & $\begin{array}{c}-1.86 * \\
-1.89 * \\
-1.82 * \\
-1.73 *\end{array}$ & & & $\begin{array}{r}-4.55^{*} \\
-4.59 * \\
-2.73^{* * *} \\
-2.71^{* * *} \\
\end{array}$ & -0.55 & & $\begin{array}{l}-3.26^{* * *} \\
-3.20^{* * *} \\
-2.57^{* * *} \\
-3.07^{* * *}\end{array}$ & & $\begin{array}{r}3.75^{* *} \\
3.75^{* *} \\
2.55^{* * *} \\
2.70^{* * *}\end{array}$ & \begin{tabular}{r|}
$3.94^{* *}$ \\
$4.12^{* *}$ \\
$7.01^{* *}$ \\
$6.14^{* * *}$
\end{tabular} & $\begin{array}{r}-0.41 \\
1.51 \\
\end{array}$ \\
\hline \begin{tabular}{|l} 
Ever \\
worked for \\
6 months \\
\end{tabular} & $\begin{array}{l}1 \text { if yes since } 6 \\
\text { years old, } \\
\text { otherwise } 0\end{array}$ & & & & & & & & & & & & & & \\
\hline Sample & Methodology & & & & & & & & & & & & & & \\
\hline Total & $\begin{array}{l}P r \\
\text { GWR }\end{array}$ & $\begin{array}{l}0.06^{* * *} \\
0.05^{* * *} \\
0.15^{* * *} \\
0.15^{* * *}\end{array}$ & $\begin{array}{r}-0.11 \\
-0.11 \\
-0.23^{* * *} \\
-0.24^{* * *}\end{array}$ & $\begin{array}{r}0.16 \\
0.14 \\
0.02 \\
-0.01 \\
\end{array}$ & \begin{tabular}{r|}
$-0.44^{* *}$ \\
$-0.47^{* *}$ \\
0.07 \\
0.1
\end{tabular} & $\begin{array}{l}2.05 * \\
2.09 *\end{array}$ & \begin{tabular}{|r|}
$0.51^{* *}$ \\
$0.48^{8 * *}$ \\
-0.13 \\
-0.2 \\
\end{tabular} & $\begin{array}{l}0.47^{* *} \\
0.52^{* *} \\
0.67^{* *} \\
0.69^{* *}\end{array}$ & $\begin{array}{l}-0.41 \\
0.09\end{array}$ & & & & & $\begin{array}{r}0.55^{* * *} \\
0.65^{* *} \\
-0.68^{* *} \\
-1.01^{* * *} \\
\end{array}$ & $\begin{array}{r}-0.05 \\
0.82^{* * * *}\end{array}$ \\
\hline Non-Arab & $\begin{array}{l}\text { Pr } \\
\text { IV }\end{array}$ & $\begin{array}{l}0.07 * \\
0.07 *\end{array}$ & $\begin{array}{l}0.01 \\
0.01\end{array}$ & $\begin{array}{l}-0.16^{* * *} \\
-0.15^{* * *} \\
\end{array}$ & $\begin{array}{r}-0.01^{* * *} \\
-0.01 \\
0.14^{*} \\
0.13^{*} \\
\end{array}$ & $\begin{array}{c}-0.05^{* *} \\
0.17^{* *}\end{array}$ & & & $\begin{array}{l}0.02 \\
0.05\end{array}$ & & $\begin{array}{l}-0.02^{* *} \\
-0.02^{* *}\end{array}$ & & $\begin{array}{l}0.02^{* * *} \\
0.02^{* * *}\end{array}$ & \begin{tabular}{r|}
$0.04^{* *}$ \\
$0.02^{* * *}$ \\
$1.58^{*}$ \\
$1.64^{*}$
\end{tabular} & $\begin{array}{l}0.03 \\
-0.3 \\
\end{array}$ \\
\hline$A r a b$ & $\begin{array}{l}\text { Pr } \\
\text { IV }\end{array}$ & $\begin{array}{l}0.16^{*} \\
0.15^{*} \\
0.14^{*} \\
0.14^{*}\end{array}$ & \begin{tabular}{l|}
$-0.14^{*}$ \\
$-0.14^{*}$ \\
$-0.18^{*}$ \\
$-0.19 *$
\end{tabular} & & \begin{tabular}{l|}
$-0.25^{* *}$ \\
$-0.24^{* *}$ \\
$-0.26^{* *}$ \\
$-0.25^{* *}$
\end{tabular} & & & & 0.14 & & $\begin{array}{l}1.16^{* *} \\
1.05^{* *} \\
1.17^{* *} \\
1.19^{* *}\end{array}$ & & $\begin{array}{l}0.36^{* *} \\
0.36^{* *} \\
0.44^{* *} \\
0.44^{* *}\end{array}$ & \begin{tabular}{r|}
$-0.19^{* * *}$ \\
$-0.32^{* *}$ \\
$-0.73^{* * *}$ \\
$-0.73^{* * *}$
\end{tabular} & $\begin{array}{l}0.33^{* *} \\
0.28^{* * *}\end{array}$ \\
\hline Male & $\begin{array}{l}\text { Pr } \\
\text { IV }\end{array}$ & $\begin{array}{c}0.11 * \\
0.11 * \\
0.08 * * \\
0.09 * * \\
\end{array}$ & $\begin{array}{c}-0.11^{*} \\
-0.11^{*} \\
-0.16^{* *} \\
-0.17^{*}\end{array}$ & \begin{tabular}{|r|}
$-0.11^{* * *}$ \\
$-0.11^{* 8}$ \\
-0.02 \\
0.01 \\
\end{tabular} & $\begin{array}{l}0.12^{* *} \\
0.13^{* *} \\
0.12^{* *} \\
0.12^{* *}\end{array}$ & & & & $\begin{array}{r}0.16 \\
0.25 * * *\end{array}$ & & $\begin{array}{l}0.84^{* * *} \\
0.79^{* * *} \\
0.84^{* * *} \\
0.90^{* * *}\end{array}$ & & $\begin{array}{r}0.24^{* * *} \\
0.23 \\
0.28^{* * *} \\
0.26^{* * *}\end{array}$ & \begin{tabular}{r|}
$-0.34^{* *}$ \\
$-0.58^{*}$ \\
-0.96 \\
$-1.10^{* * *}$ \\
\end{tabular} & $\begin{array}{r}0.52^{*} \\
0.28^{* * *}\end{array}$ \\
\hline Female & $\mathrm{Pr}$ & $\begin{array}{c}0.07 * \\
0.07 *\end{array}$ & $\begin{array}{c}-0.08^{* * *} \\
-0.08^{* * *} \\
-0.17^{* *} \\
-0.17^{* *}\end{array}$ & $\begin{array}{r}0.10^{* * * *} \\
0.08 \\
0.31^{*} \\
0.29 * \\
\end{array}$ & \begin{tabular}{r|}
$-0.33^{*}$ \\
$-0.33^{*}$ \\
$-0.31^{* *}$ \\
$-0.31^{* *}$
\end{tabular} & & & & -0.16 & & & & $\begin{array}{l}0.37^{* * *} \\
0.39^{* * *} \\
0.41^{* * *} \\
0.40^{* * *}\end{array}$ & $\begin{array}{r}-0.21 \\
-0.18 \\
-1.93 * \\
-1.83 * *\end{array}$ & 0.04 \\
\hline
\end{tabular}

Results of the GWR estimation provided changing regional effects on the coefficients of number of siblings and of household members. These impacts were presented in Figure 2, and in Appendix Figures 1 and 2. In these graphs the effects gets bigger as the governorates gets darker. Therefore, regional coefficients on number of siblings and household members did not change direction compared to global coefficients. In general, in Mafraq, the number of siblings and household members were observed to have a stronger effect compared to global impact; Madaba and then Zarqa had the slightest impact among regions ${ }^{8}$.

At this stage we may conclude that the heterogeneity with respect to migrants' education level in different governorates does only play a significant role in Mafraq where the share of migrants with basic education reached almost $32 \%$. In this governorate, where presumably

${ }^{8}$ Among all explanatory variables, estimated coefficients of only two variables were found to differ with respect to different governorates. Therefore the maps show only those variables. The estimated coefficients of the two variables are statistically significant and the diagnostic test results of GWR estimations can be delivered upon request. 


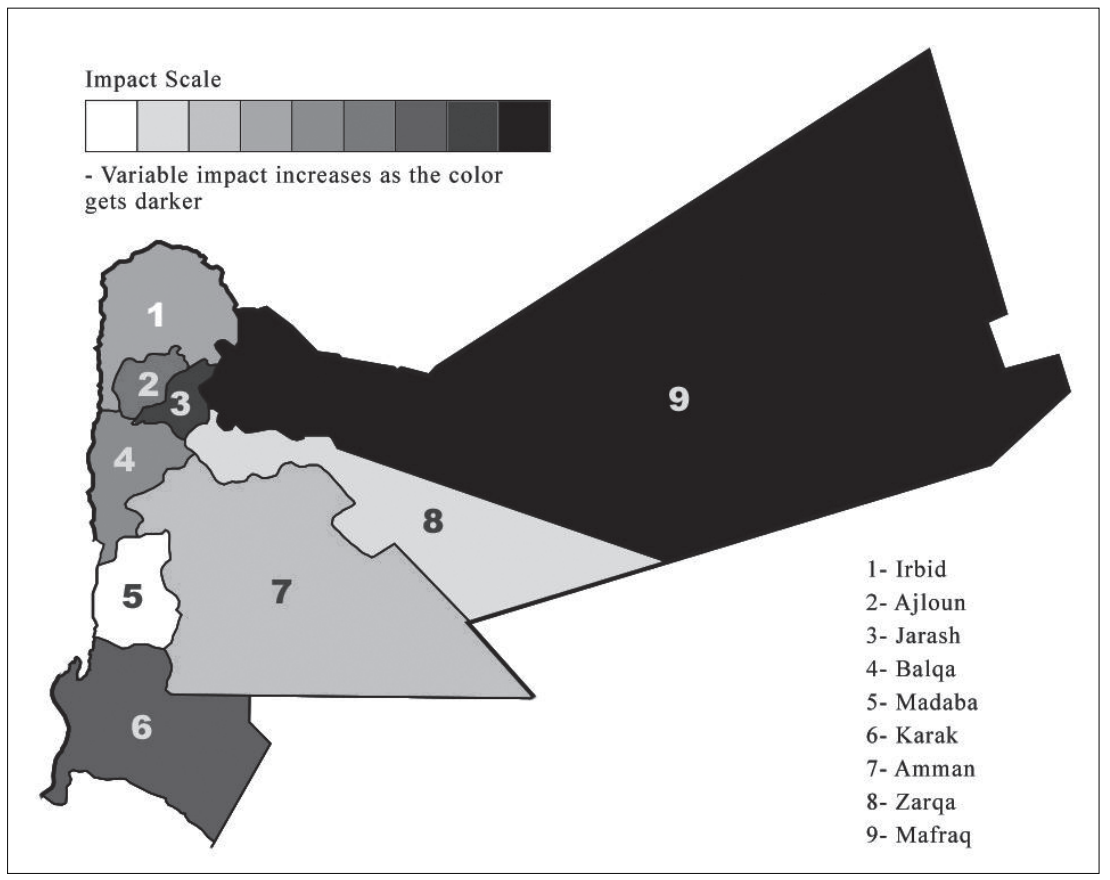

Figure 2 - Impact of Number of Siblings by Region ( $1^{\text {st }}$ Equation).

there is lack of job opportunities for even low qualified labour and probably relatively more poverty, an increasing number of siblings creates more negative impact on schooling in comparison to other governorates. Likewise, a rising number of household members creates more positive impact compared to other governorates, which might be due to the rising number of income earners in the household.

The other common variable among models that was statistically significant was the wealth of households. Household wealth seemed to create a negative impact on schooling level, and findings with regard to schooling level did not change with respect to host country groups. As this is a common finding, we believe education might not be the main priority in the home country, rather the priority is achieving higher living standards due to received remittances.

Emigrants' last visit to their home was another common variable among various models that was found to be statistically significant. As the time since the emigrant last visited his/her home increased, this seemed to create a negative impact on the possibility of having a higher schooling level. The findings did not seem to change across households where the emigrants chose to migrate to Non-Arab and Arab countries.

\section{Discussion and Conclusions}

Empirical findings can be evaluated from various angles, but one thing is certain: to create an enabling effect of remittances, the disabling impact of migration in other words, family disruption channel, should be removed.

At the macro level, the institutional framework that deals with the transfer of migration returns (remittances) to households, and with the valuation of remittances into investments and productive use and/or consumption should be improved to enforce an efficient and transparent environment. The productive use of remittances, and/or rising expenditures on basic needs including health and education or on human capital formation, should be rewarded and enabled through the implementation of well-designed economic policy measures. Therefore the issue requires both macro and micro policy instruments to channel remittances to any sort of productive and beneficial activities. 
At the household level, channelling remittances into human capital formation is not only about the use of money; it is rather related more with cultural and socio-economic characteristics of the households and where they reside. This study about Jordan, in particular, provides some evidence to support this last argument.

In general, the empirical findings suggest that a positive impact of remittances on human capital formation is highly related with household structure, such as the number of siblings and of household members. However, to derive more solid conclusions, knowing the age and gender distribution of household members, including siblings, their education levels and occupation, is essential. The education level of the migrants, their pre- and post-migration occupation, and the main purpose as emigrants should be known. The routine that migrants get in touch with the left behind, and their intention to closely follow the daily routine of the left behind, are all important factors that lead to the efficient use of remittances.

In the case of Jordan, statistics show that a highly skilled labour force prefers to migrate to oil-rich Arab countries. Therefore, one should expect higher factor rewards in these countries. This fact is quite contrary to what has been observed in other oil-poor Middle Eastern countries, where a low skilled labour force migrates to oil-rich Arab countries. The empirical evidence in this study does not suggest a strong and solid difference among household behaviour that has sent migrants to Non-Arab and Arab countries. We might expect that highly-skilled labour also migrates to Non-Arab countries. There is not enough empirical evidence that suggests a significant difference between human capital formation of boys and girls left behind. However, some statistical evidence of difference is found between home governorates, meaning that the number of siblings and household members present changes the impact on human capital formation. In addition, the level of household wealth and absence of both parents also had different impacts on human capital formation. These changing impacts should definitely be ex- plained by cultural and socio-economic specifics of these governorates.

The literature reviewed in Section 3 provides quite mixed findings with respect to the impact of remittances on income and family disruption. It is not easy to conclude some solid and may be consistent outcomes from these empirical works. The difficulty arises due to various factors, such as the differences in indicators to proxy, for example, "schooling" and "family disruption", in regional focus and time period in specific characteristics of the origin and host countries, and in factors that motivate migrant characteristics.

Among all the literature, two studies (Cuecuecha, 2009, and Amuedo-Dorantes et al., 2010), are more similar to our research, at least with respect to subject focus and findings. They both analyze income and family disruption impacts of remittances at the same time and find the overall impact as positive, which is consistent with our findings in this research. However, their country focus is Mexico and the Dominican Republic respectively.

The findings of the four studies on Egypt (Elbadawy and Roushdy, 2010; Binzel and Assaad, 2008, 2011; and Koska et al. 2013) are quite mixed, except for Koska et al. (2013), which also analyzes income and family disruption effects together and finds outcomes consistent with our findings. The only study that focuses on Jordan is Mansour et al. (2011). They analyze the impact of remittances only on "schooling", and their findings are quite consistent with ours, at least regarding "schooling"; however, there is solid empirical evidence in that paper, showing that the impacts do change by gender, which we cannot provide in our research. We believe the uniqueness of this research arises due to several factors, such as the chosen instrumental variable, the way of quantifying the family disruption effect, and the empirical information provided at the governorate and host country level.

\section{Acknowledgements}

We are grateful to Economic Research Forum (www.erf.org.eg) for providing us the data set. 


\section{References}

Acosta P., 2011a. School attendance, child labour, and remittances from international migration in El Salvador. Journal of Development Studies, 47(6): 913-936.

Acosta P., 2011b. Female migration and child occupation in rural El Salvador. Population Research Policy Review, 30(4): 569-589.

Adams R.H., 2005. Remittances, Household Expenditure and Investment in Guatemala. Policy Research Working Paper 3532.Washington, DC: The World Bank.

Adams Jr, R.H., 2011. Evaluating the economic impact of international remittances on developing countries using household surveys: A literature review. Journal of Development Studies, 47(6): 809-828.

Adams Jr, R.H., Cuecuecha A., 2010. Remittances, household expenditure and investment in Guatemala. World Development, 38(11): 1626-1641.

Alcaraz C., Chiquiar D., Salcedo A., 2012. Remittances, schooling, and child labor in Mexico. Journal of Development Economics, 97(1): 156-165.

Amuedo-Dorantes C., Georges A., Pozo S., 2010. Migration, remittances, and children's schooling in Haiti. The Annals of the American Academy of Political and Social Science, 630(1): 224-244.

Amuedo-Dorantes C., Pozo S., 2010. Accounting for remittance and migration effects on children's schooling. World Development, 38(12): 17471759 .

Antman F.M., 2011. The intergenerational effects of paternal migration on schooling and work: What can we learn from children's time allocations? Journal of Development Economics 96(2): 200-208.

Arguillas M.J.B., Williams L., 2010. The impact of parents' overseas employment on educational outcomes of Filipino children. International Migration Review, 44(2): 300-319.

Atamanov A., Van den Berg M., 2012. Heterogeneous Effects of International Migration and Remittances on Crop Income: Evidence from the Kyrgyz Republic, World Development, 40(3): 620-630.

Bansak C., Chezum B., 2009. How do remittances affect human capital formation of school-age boys and girls? American Economic Review: Papers and Proceedings, 99(2): 145-148.

Binzel C., Assaad R., 2008. The impact of international migration and remittances on domestic labor markets: Evidence from Egypt. Mimeo.

Binzel C., Assaad R., 2011. Egyptian men working abroad: Labour supply responses by the women left behind. Labour Economics, 18(1): S98-S114.
Boucher S., Stark O., Taylor J.E., 2009. A gain with a drain? Evidence from rural Mexico on the new economics of the brain drain. In Kornai J., Mátyás L. and Roland G. (eds). Corruption, development, and institutional design. Basingstoke: Palgrave Macmillan, 100-119.

Bredl S., 2011. Migration, remittances and educational outcomes: The case of Haiti. International Journal of Educational Development, 31(2): 162-168.

Calero C., Bedi A.S., Sparrow R., 2009. Remittances, liquidity constraints and human capital investments in Ecuador. World Development, 37(6): 1143-1154.

CARIM (Consortium for Applied Research on International Migration), 2010. Migration Profile: Jordan, Robert Schuman Centre for Advanced Studies, November.

Chami R., Fullenkamp C., Jahjah S., 2003. Are Immigrant Remittance Flows a Source of Capital for Development? International Monetary Fund Working Paper 03/189. Washington, DC: International Monetary Fund.

Cortes P., 2015. The Feminization of International Migration and its Effects on the Children Left Behind: Evidence from the Philippines. World Development, 65: 62-78.

Cuecuecha A., 2009. The effect of remittances and migration on human capital: Evidence from Mexico, CIDE Working Paper No. 455, Lomas Santa Fe: Centro de Investigación y, Docencia Económicas (CIDE).

Edwards A.C., Ureta M., 2003. International migration, remittances, and schooling: Evidence from El Salvador. Journal of Development Economics, 72(2): 429-461.

Elbadawy A., Roushdy R., 2010. Impact of international migration and remittances on child schooling and child work: The case of Egypt, Economic Research Forum Working Paper 545, Cairo: The Economic Research Forum.

Hanson G.H., Woodruff C., 2003. Emigration and educational attainment in Mexico. Mimeo.

Kandel W., Kao G., 2001. The impact of temporary labour migration on Mexican children's educational aspirations and performance. International $\mathrm{Mi}$ gration Review, 35(4): 1205-1231.

Katz E., Stark O., 1986. Labor migration and risk aversion in less developed countries. Journal of Labour Economics, 4(1): 134-149.

Koska A.O., Saygın P.Ö., Çağatay S., Artal-Tur A., 2013. International Migration, Remittances, and the Human Capital Formation of Egyptian Children. International Review of Economics and Finance, 28: 38-50. 
Kroeger A., Anderson K.H., 2013. Remittances and the human capital of children: New evidence from Kyrgyzstan during revolution and financial crisis, 2005-2009. Journal of Comparative Economics, 42(3): 770-785.

León-Ledesma M., Piracha M., 2004. International Migration and the Role of Remittances in the Eastern Europe. International Migration, 42(4): 65-83.

Lopez-Cordova E., 2005. Globalization, migration, and development: The role of Mexican migrant remittances. Economía, 6: 217-256.

Mansour W., Chaaban J., Litchfield J., 2011. The Impact of Migrant Remittances on School Attendance and Education Attainment: Evidence from Jordan. International Migration Review, 45(4): 812-851.

Mansuri G., 2006. Migration, school attainment and child labor: Evidence from rural Pakistan, World Bank Policy Research Paper 3945, Washington DC: The World Bank.

Massey D.S., 1990. Social structure, household strategies, and the cumulative causation of migration. Population Index 56: 3-26.

Massey D.S., Arango J., Hugo G., Kouaouci A., Pellegrino A., Taylor J.E., 1993. Theories of international migration: a review and appraisal. Population and Development Review 19: 431-466.

Massey D.S., Arango J., Hugo G., Kouaouci A., Pellegrino A., Taylor J.E., 1994. An evaluation of international migration theory: the North American case. Population and Development Review 20: 699-751.

Mckenzie D., Rapoport H., 2011. Can migration reduce educational attainment? Evidence from Mexico. Journal of Population Economics, 24(4): 1331-1358.

Mckenzie D., Sasin M.J., 2007. Migration, remittances, poverty, and human capital: Conceptual and empirical challenges, World Bank Policy Research Paper 4272, Washington DC: The World Bank.

Piracha M., Saraogi A., 2012. The Determinants of Remittances: Evidence from Moldova, Oxford Development Studies, 40(4): 467-491.

Rapoport H., Docquier F., 2006. The economics of migrants' remittances: In Kolm S.C. and Mercier-Ythier J. (eds). Handbook of the economics of giving, altruism and reciprocity. Amsterdam: Elsevier-North Holland, 1135-1198.
Ratha D., 2007. Leveraging Remittances for Development, Migration Policy Institute, Washington, DC.

Ratha D., Xu Z., 2008. Migration and Remittance Factbook, Development and Prospects Group. Washington, DC: The World Bank.

Ratha D., Mohapatra S., Scheja E., 2011. Impact of migration on economic and social development: $A$ review of evidence and emerging issues, World Bank Policy Research Paper 5558, Washington DC: The World Bank.

Robles V.F., Oropesa R.S., 2011. International migration and the education of children: Evidence from Lima, Peru. Population Research and Policy Review, 30(4): 591-618.

Salas V.B., 2014. International Remittances and Human Capital Formation. World Development, 59: 224-237.

Schapiro K.A., 2009. Migration and educational outcomes of children, Human Development Research Paper 2009/57, New York: United Nations Development Programme.

Stark O., 1984. Discontinuity and the Theory of International Migration. Kyklos, 37(2): 206-222.

Stark O., Bloom D.E., 1985. The new economics of labour migration. American Economic Review, 75(2): 173-178.

Stark O., Byra L., 2012. A back-door brain drain. Economics Letters, 116(3): 273-276.

Stark O., Helmenstein C., Prskawtez A., 1997. A brain gain with a brain drain. Economics Letters, 55(2): 227-234.

Stöhr T., 2015. Siblings' interaction in migration decisions: who provides for the elderly left behind? Journal of Population Economics, 28(3): 593-629.

World Bank, 2008. Migration and Remittances Factbook 2008, World Bank, Washington, DC.

Yang D., 2008. International migration, remittances and household investment: Evidence from Philippine migrants' exchange rate shocks. The Economic Journal, 118(528): 591-630.

Zhunio M.C., Vishwasrao S., Chiang E.P., 2012. The influence of remittances on education and health outcomes: a cross country study. Applied Economics, 44(35): 4605-4616.

http://europa.eu/rapid/press-release_IP-14-1109_en. htm. (30th October 2014). 


\section{Appendix}

Table A1 - Some Statistical Information Regarding Migrant Households.

\begin{tabular}{|c|c|c|c|}
\hline Individuals & 25.969 & \multicolumn{2}{|c|}{$\begin{array}{c}\text { Distribution of Emigrants } \\
\text { by Governorate- } \%\end{array}$} \\
\hline Households & 5000 & Amman & 35,77 \\
\hline Individuals in migrant households & 753 & Irbid & 19,15 \\
\hline Individuals between age 6-30 in migrant households & 384 & Zarqa & 15,16 \\
\hline \# of remittance receiving individuals & 260 & Ajloun & 9,18 \\
\hline Households in which both parents are migrants & 76 & Jarash & 7,98 \\
\hline \# of male/female left behind (age 6-30) & $183 / 201$ & Balqa & 5,19 \\
\hline \# of emigrants in Non-Arab countries & 69 & Karak & 3,46 \\
\hline \multirow[t]{2}{*}{ \# of emigrants in Non-Arab countries } & 315 & Mafraq & 2,53 \\
\hline & & Madaba & 1,60 \\
\hline
\end{tabular}

Source: Authors'calculations.

Table A2 - Distribution of Migrants by Destination-\%.

\begin{tabular}{|l|c|}
\hline Major Oil Exporting Arab Countries & 73,00 \\
USA & 11,62 \\
Europe & 7,14 \\
Other Arab Countries & 3,03 \\
Canada & 1,82 \\
Columbia & 1,69 \\
Australia & 0,97 \\
Kazakhstan & 0,36 \\
Afghanistan & 0,36 \\
\hline
\end{tabular}

Source: Authors'calculations. 
Table A3 - Education Level of Migrants by Destination and by Origin Governorates-\%.

\begin{tabular}{|c|c|c|c|c|c|c|c|c|c|}
\hline $\begin{array}{l}\text { By } \\
\text { Destination }\end{array}$ & $\begin{array}{c}\text { Post- } \\
\text { graduate } \\
\text { Degree }\end{array}$ & $\begin{array}{c}\text { Bachelor } \\
\text { Degree }\end{array}$ & $\begin{array}{c}\text { Intern } \\
\text { Diploma }\end{array}$ & $\begin{array}{c}\text { Secondary } \\
\text { School }\end{array}$ & $\begin{array}{c}\text { Vocational } \\
\text { School }\end{array}$ & $\begin{array}{c}\text { Basic } \\
\text { Education }\end{array}$ & $\begin{array}{l}\text { Preparity } \\
\text { Education }\end{array}$ & $\begin{array}{c}\text { Primary } \\
\text { School }\end{array}$ & Literate \\
\hline Afghanistan & 0,00 & 100,00 & 0,00 & 0,00 & 0,00 & 0,00 & 0,00 & 0,00 & 0,00 \\
\hline Australia & 50,00 & 50,00 & 0,00 & 0,00 & 0,00 & 0,00 & 0,00 & 0,00 & 0,00 \\
\hline Canada & 100,00 & 0,00 & 0,00 & 0,00 & 0,00 & 0,00 & 0,00 & 0,00 & 0,00 \\
\hline Columbia & 100,00 & 0,00 & 0,00 & 0,00 & 0,00 & 0,00 & 0,00 & 0,00 & 0,00 \\
\hline Europe & 39,73 & 8,22 & 23,29 & 5,48 & 5,48 & 9,59 & 5,48 & 0,00 & 2,74 \\
\hline Kazakhastan & 0,00 & 0,00 & 100,00 & 0,00 & 0,00 & 0,00 & 0,00 & 0,00 & 0,00 \\
\hline $\begin{array}{l}\text { Major Oil } \\
\text { Exp. Arab C. }\end{array}$ & 51,08 & 16,25 & 11,77 & 1,66 & 5,80 & 7,63 & 2,82 & 2,49 & 0,50 \\
\hline $\begin{array}{l}\text { Other Arab } \\
\text { Countries }\end{array}$ & 20,00 & 16,00 & 0,00 & 0,00 & 16,00 & 0,00 & 48,00 & 0,00 & 0,00 \\
\hline USA & 55,21 & 12,50 & 18,75 & 5,21 & 6,25 & 2,08 & 0,00 & 0,00 & 0,00 \\
\hline $\begin{array}{l}\text { By Origin } \\
\text { Governorate }\end{array}$ & $\begin{array}{c}\text { Post- } \\
\text { graduate } \\
\text { Degree }\end{array}$ & $\begin{array}{c}\text { Bachelor } \\
\text { Degree }\end{array}$ & $\begin{array}{c}\text { Intern } \\
\text { Diploma }\end{array}$ & $\begin{array}{c}\text { Secondary } \\
\text { School }\end{array}$ & $\begin{array}{c}\text { Vocational } \\
\text { School }\end{array}$ & $\begin{array}{c}\text { Basic Ed- } \\
\text { ucation }\end{array}$ & $\begin{array}{l}\text { Preparity } \\
\text { Education }\end{array}$ & $\begin{array}{l}\text { Primary } \\
\text { School }\end{array}$ & Literate \\
\hline Ajloun & 39,13 & 15,94 & 39,13 & 0,00 & 0,00 & 5,80 & 0,00 & 0,00 & 0,00 \\
\hline Amman & 58,74 & 13,38 & 7,81 & 4,46 & 7,43 & 3,35 & 2,60 & 0,74 & 1,49 \\
\hline Balqa & 12,82 & 33,33 & 5,13 & 7,69 & 10,26 & 30,77 & 0,00 & 0,00 & 0,00 \\
\hline Irbid & 51,39 & 12,50 & 14,58 & 0,00 & 12,50 & 7,64 & 0,00 & 0,00 & 1,39 \\
\hline Jarash & 5,95 & 5,20 & 3,72 & 0,00 & 2,23 & 4,09 & 1,12 & 0,00 & 0,00 \\
\hline Karak & 84,62 & 0,00 & 15,38 & 0,00 & 0,00 & 0,00 & 0,00 & 0,00 & 0,00 \\
\hline Madaba & 66,67 & 0,00 & 8,33 & 0,00 & 0,00 & 0,00 & 25,00 & 0,00 & 0,00 \\
\hline Mafraq & 47,37 & 0,00 & 21,05 & 0,00 & 0,00 & 31,58 & 0,00 & 0,00 & 0,00 \\
\hline Zarqa & 37,72 & 23,68 & 13,16 & 0,00 & 0,00 & 0,00 & 17,54 & 7,89 & 0,00 \\
\hline
\end{tabular}

Source: Authors' calculations. 
Figure A1 - Impact of Number of Household Members by Region ( $1^{\text {st }}$ Equation $)$.

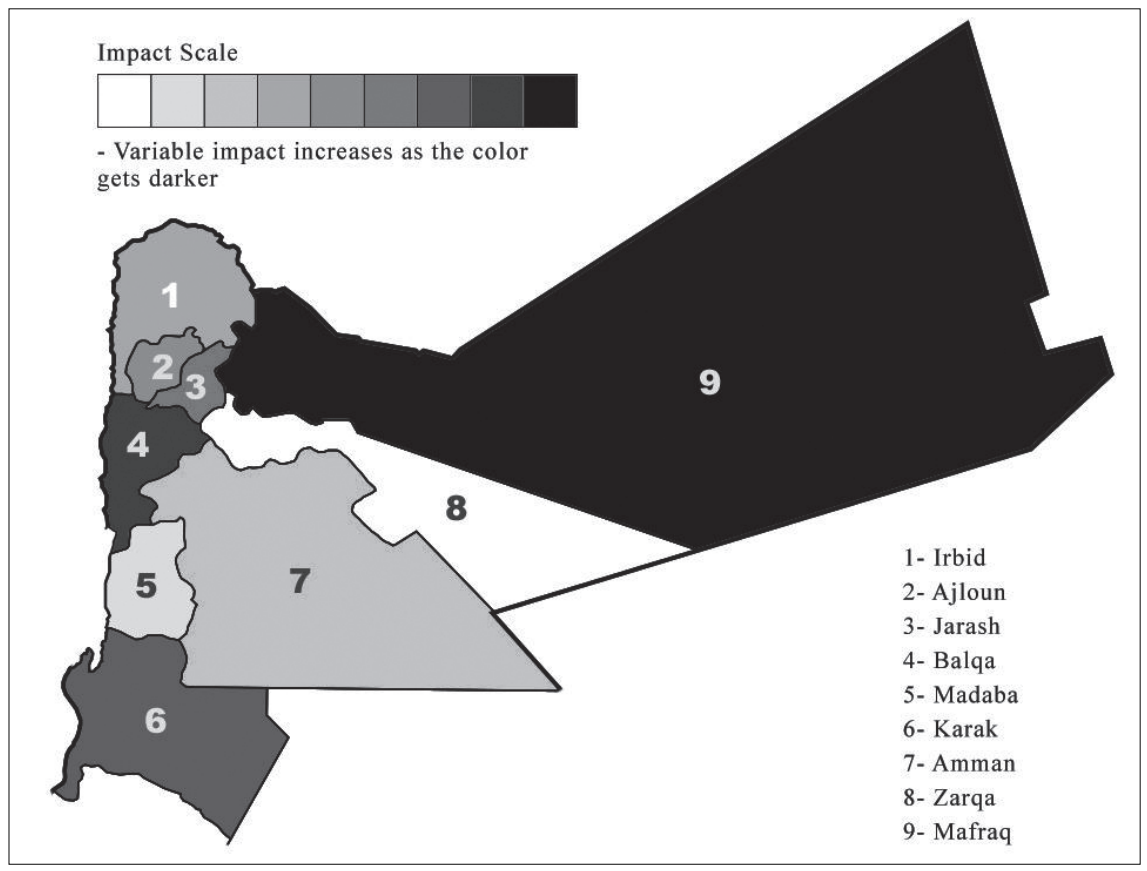

Figure A2 - Impact of Number of Household Members by Region (2 ${ }^{\text {nd }}$ Equation).

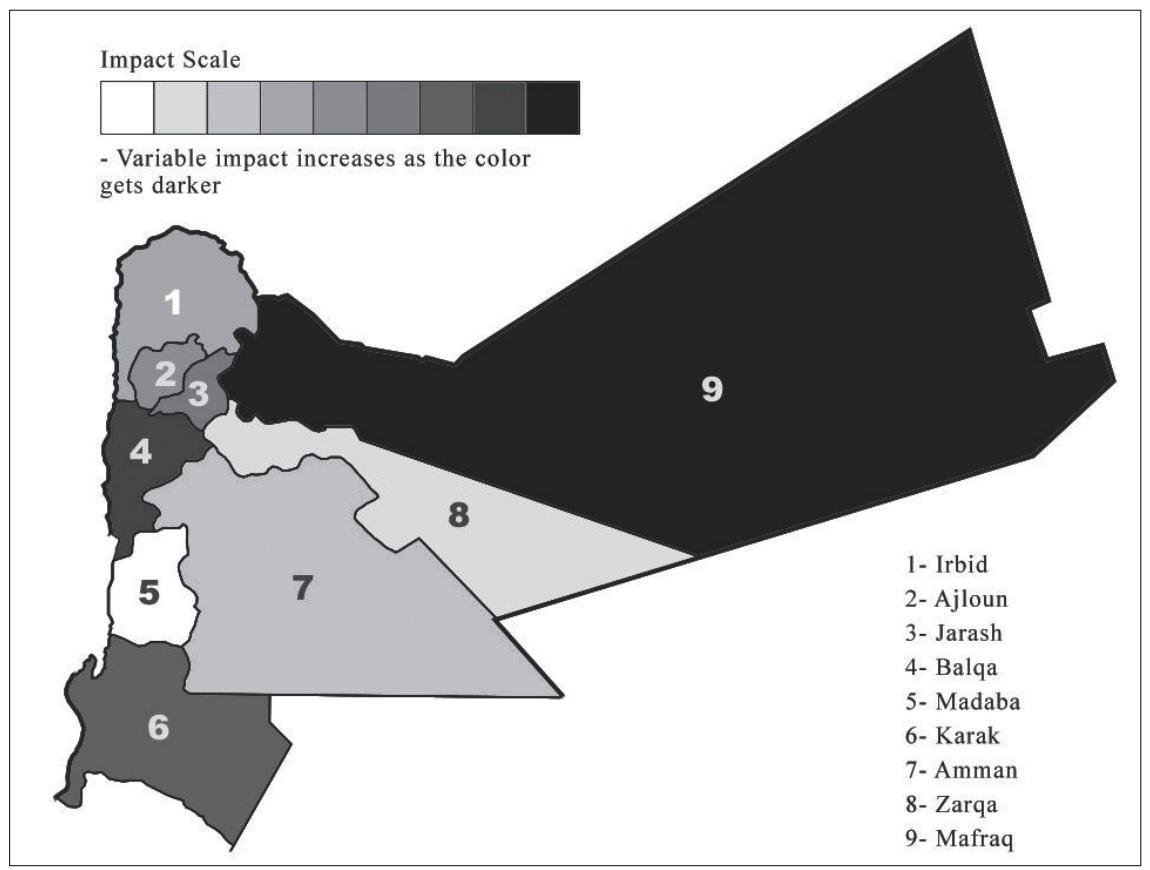

